\title{
Physicochemical Study on the Effectiveness of Eco-Friendly Anti-Corrosion Agent on the Corrosion of Steel in $\mathrm{H}_{3} \mathrm{PO}_{4}$ Solution \\ Hanaa Hammam ABDEL-RAHMAN, ${ }^{a}$ * Afaf Mahmoud HAFEZ, ${ }^{b}$ and Amr Ahmed HELMYb
}

a Chemistry Department, Faculty of Science, Alexandria University, Alexandria, Egypt

b Department of Environmental studies Institute of Graduate Studies and Research, Alexandria University, Alexandria, Egypt

* Corresponding author: hhabdelrahman10@yahoo.ca

\begin{abstract}
The inhibitory effect of extract of Hibiscus Sabdariffa on corrosion of steel in aqueous $8 \mathrm{M} \mathrm{H}_{3} \mathrm{PO}_{4}$ was investigated by potentiodynamic polarization technique. The inhibition efficiency of Hibiscus extract on corrosion of steel in aqueous $8 \mathrm{M} \mathrm{H}_{3} \mathrm{PO}_{4}$ solution increases on increasing in concentration of the extract and decreases with a rise in temperature. Potentiodynamic polarization measurement indicates that Hibiscus acts as a corrosion inhibitor. Theoretical fitting of the different isotherms were tested to clarify the nature of adsorption. The increase in activation energy of corrosion process in the presence of the extract indicates that the extract retards the rate of corrosion of steel in $8 \mathrm{M} \mathrm{H}_{3} \mathrm{PO}_{4}$ solution. The structure and morphology of the extract were characterized by Fourier transform infrared spectroscopy (FTIR). Scanning electron microscopy (SEM) study confirmed the adsorption of inhibitor molecules on steel surface.
\end{abstract}

(C) The Electrochemical Society of Japan, All rights reserved.

Keywords : Steel, Corrosion Inhibitor, Adsorption, Potentiodynamic Polarization

\section{Introduction}

Corrosion is an electrochemical phenomenon and is accompanied by the flow of electrical current. Steel is largely used in many industries due to its easy availability, ease of fabrication, low cost and good tensile besides various other desirable properties. Consequently, several authors conducted a lot of studies to find effective inhibitors for steel in different media. ${ }^{1-10}$ Acids solutions are widely used in many industries such as pickling, cleaning, descaling, storage of acids and other chemical processes. Because of the aggressiveness of the acids, the use of inhibitors is one of the most practical methods for protection against corrosion, especially in acid solutions to reduce the rate of dissolution of metals. Although many synthetic compounds show good anticorrosive properties, most of them are highly toxic to both human beings and environments. ${ }^{11}$ These inhibitors may cause temporary or permanent damage to human organ such as kidney or liver. ${ }^{2,12}$ The known hazardous effects of most synthetic organic inhibitors and restrictive environmental regulations have now made researchers to focus on the need to develop cheap, non-toxic and environmental friendly natural products as inhibitors.

The protection of metals or alloys against corrosion can be achieved either by special treatment of the medium to depress its aggressiveness or by introducing into it small amounts of special substances called corrosion inhibitors. Inhibitors are classified according to their action (as anodic, cathodic and mixed inhibitors) and according to their mechanism of action (as hydrogen evolution, scavengers, vapor-phase and adsorption inhibitors). Green inhibitors are more environmental benign than organic and inorganic inhibitors. The alternative way to minimize the risk of organic and inorganic inhibitors is the adsorption of green inhibitor to reduce the environmental hazard. ${ }^{13,14}$

The use of the natural products such as extracted compounds as corrosion inhibitors have been widely reported by several authors. ${ }^{15-18}$ Leaf extract was reported as good corrosion inhibitors for steel in $\mathrm{HCl}$ and $\mathrm{H}_{2} \mathrm{SO}_{4}$. The inhibition performance of plant extract is normally ascribed to the presence in their composition of complex organic species such as carbohydrates, amino acids, tannins, alkaloids and protein as well as hydrolysis products. The natural inhibitors are non-expensive, renewable, easily available and in particular environmental friendliness.

Hibiscus sabdariffa L. or roselle is used in jams, jellies, sauces and wines. The young leaves and tender stem are eaten raw in salads and chutney. The compositions contained in the flowers of Hibiscus species are polyphenolic acids, flavonoids, and anthocyanins. ${ }^{19}$ Many medicinal applications of this plant have been developed around the world. Contains many antioxidants so it protects against cancer, reduces LDL cholesterol and thus is useful for patients with diabetes, contains anti-inflammatory, protects against heart disease and hardening of the arteries, relieves cramps and reduces cases of mood swings and depression because it contains flavonoid compound, strengthens the immune system because it contains a high content of vitamin $\mathrm{C}$, so it is an effective anti-bacterial and prevent colds and flu and an active role in improving digestive health is good diuretic and orderly movement of the intestine and therefore protects against colorectal cancer.

This work is another trail to find a naturally occurring cheap and environmentally safe substance that could be used for inhibiting the corrosion of steel in $8 \mathrm{M} \mathrm{H}_{3} \mathrm{PO}_{4}$. The inhibition effect of Hibiscus Sabdariffa was investigated by potentiodynamic polarization. Thermodynamic data as well as the activation energy were obtained from Arrhenius plots. SEM study was also used to study the surface morphologies.

\section{Experimental Methods}

\subsection{Preparation of plant extract}

The leaves of Hibiscus Sabdariffa were dried for 6 hours in an oven at $70^{\circ} \mathrm{C}$ and ground into powder and 10 grams of the powder of Hibiscus Sabdariffa was refluxed in $100 \mathrm{ml}$ double distilled water for 1 hour. The aqueous solution was filtered and concentrated to $100 \mathrm{ml}$. This concentrated solution was used to prepare a solution of different concentrations by dilution method. 


\subsection{Potentiodynamic measurements}

The cell used in the present work consists of a rectangular plastic container having the dimensions $10 \times 5 \times 10 \mathrm{~cm}$ with electrodes fitting the whole cross section. The electrodes were rectangular steel sheets of $10 \mathrm{~cm}$ height and $5 \mathrm{~cm}$ width. Electrode separation was $5 \mathrm{~cm}$; a porous $\mathrm{PVC}$ diaphragm was used to prevent the stirring effect due to $\mathrm{H}_{2}$ bubbles evolved at the cathode. The electrical circuit consists of 6 V D.C. power supply, a variable resistance and a multi range ammeter connected in series with cell. A high impedance voltammeter was connected in parallel with the cell to measure its potential. Five concentrations of phosphoric acid $(6,8,10,12$ and $14 \mathrm{M}$ ) were prepared from analar grade $\mathrm{H}_{3} \mathrm{PO}_{4}(95 \%)$. Five concentrations of Hibiscus Sabdariffa solutions with $8 \mathrm{M} \mathrm{H}_{3} \mathrm{PO}_{4}$ are used. The steady state anode potential was measured against a reference electrode consisted of steel wire immersed in a cup of luggin tube filled with a solution similar to that in the cell. The tip of the luggin tube was placed $0.5-1 \mathrm{~mm}$ from anode wall. Polarization curves, from which the limiting current was determined, were plotted by increasing the applied current stepwise and measuring the corresponding steady-state potential. Before each run, the back part of the anode was insulated with polystyrene lacquer and the active surface of the anode was polished with a fine grade paper, degreased with trichloroethylene, washed with alcohol and finally rinsed in distilled water. The temperature was regulated by placing the cell in the thermostatic water bath at different temperatures $(25,30,35$ and $40^{\circ} \mathrm{C}$ ). The steel used had the following chemical composition (weight \%): 0.2 C, 0.04 S, 2.6 Mn, 0.039 P, 0.36 Si and 96.761 Fe.

\subsection{Scanning electron microscope analysis (SEM)}

The scanning electron microscope images were taken using (JEOL, JSM-5300, scanning microscope, OXFORD instrument). Sample for SEM experiments where iron sheet anode was $(1 \mathrm{~cm} \times$ $1 \mathrm{~cm})$.

\section{Results and Discussion}

\subsection{Characterization of plant extract}

In order to have a better idea of which components of this plant extract are responsible for the decrease in the corrosion rate of $\mathrm{Fe}$, an FTIR analysis was performed, and the results are shown in Fig. 1, which shows the presence of original absorption at $3433 \mathrm{~cm}^{-1}$ (associated hydroxyl) was overlapped by the strong stretching mode of $\mathrm{N}-\mathrm{H}$ or $\mathrm{O}-\mathrm{H}$ and that at $1959 \mathrm{~cm}^{-1}$ is related to $\mathrm{C}-\mathrm{H}$ stretching vibration. The strong band at $1757 \mathrm{~cm}^{-1}$ is assigned to $\mathrm{C}=\mathrm{O}$ stretching vibration. The strong band at $1641 \mathrm{~cm}^{-1}$ is assigned to $\mathrm{C}=\mathrm{C}, \mathrm{C}=\mathrm{C}$ and $\mathrm{C}=\mathrm{O}$ stretching vibration bands are superposition. The ether group was observed at $1086 \mathrm{~cm}^{-1}$. The adsorption bands at $1223 \mathrm{~cm}^{-1}$ could be assigned to the framework vibration of aromatic ring. ${ }^{20}$

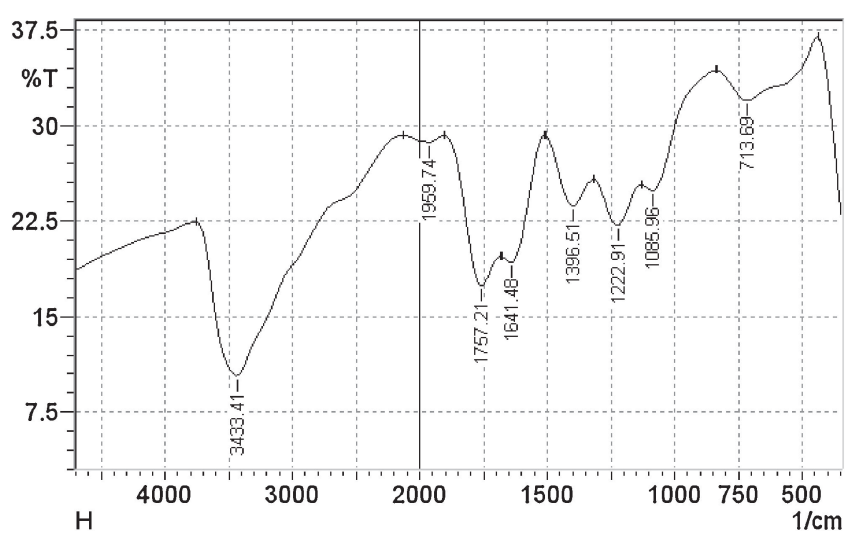

Figure 1. FTIR spectra of Hibiscus Sabdariffa.
The IR spectrum analysis confirmed the Hibiscus sabdariffa extract contained flavonoid compounds which have a chemical structure as shown in Fig. 2. The presence of functional groups such as $\mathrm{OH}$ and $=\mathrm{O}$ may be responsible for the decrease in the corrosion rate, since they can react with the $\mathrm{Fe}^{2+}$ ions. This is an agreement with the previously reported data by C. Monticelli et al. ${ }^{21}$

\subsection{Corrosion of steel in $\mathrm{H}_{3} \mathrm{PO}_{4}$ without Hibiscus Sabdariffa}

Figure 3 shows a set of a typical current potential curve obtained at different $\mathrm{H}_{3} \mathrm{PO}_{4}$ acid concentrations. Polarization curves, from which the limiting current $\left(I_{L}\right)$ was determined, were plotted by increasing the applied current stepwise and measuring the corresponding steady-state potential. It is obvious that the limiting current decreases with increasing $\mathrm{H}_{3} \mathrm{PO}_{4}$ acid concentrations within the range studied (6-14 M) at different temperatures (Fig. 4). This is in agreement with the finding of other authors who worked within

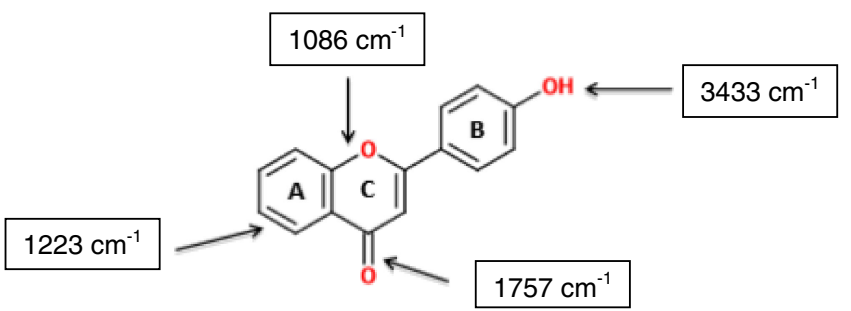

Figure 2. (Color online) The important functional groups in general structure of flavonoids and their IR frequencies.

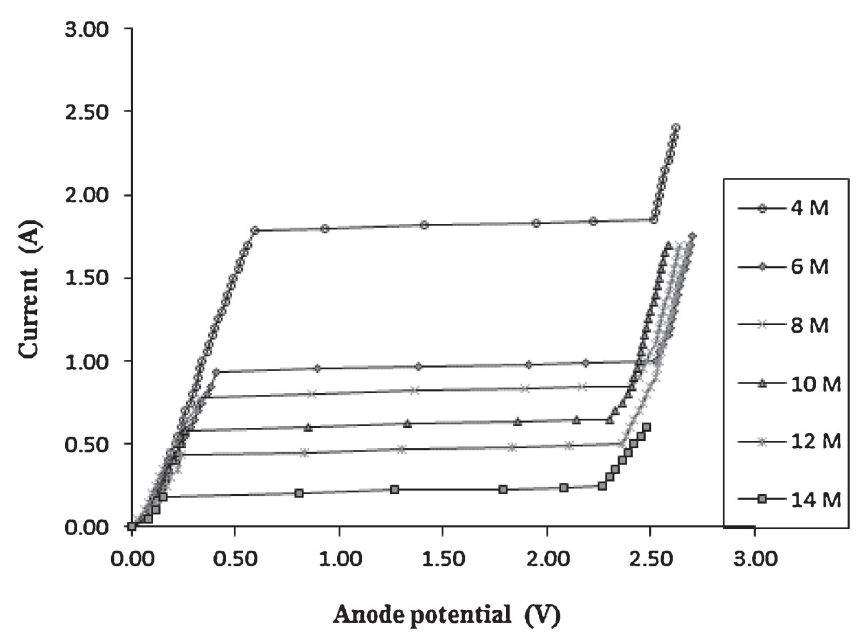

Figure 3. Typical polarization curves for steel in the presence of different concentrations of $\mathrm{H}_{3} \mathrm{PO}_{4}$ acid at $298 \mathrm{~K}$.

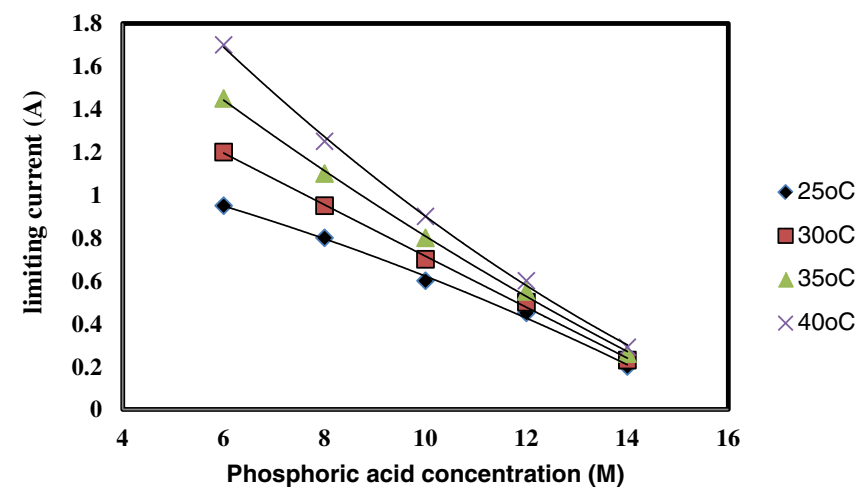

Figure 4. (Color online) Effect of phosphoric acid concentration on the limiting current at different temperatures. 


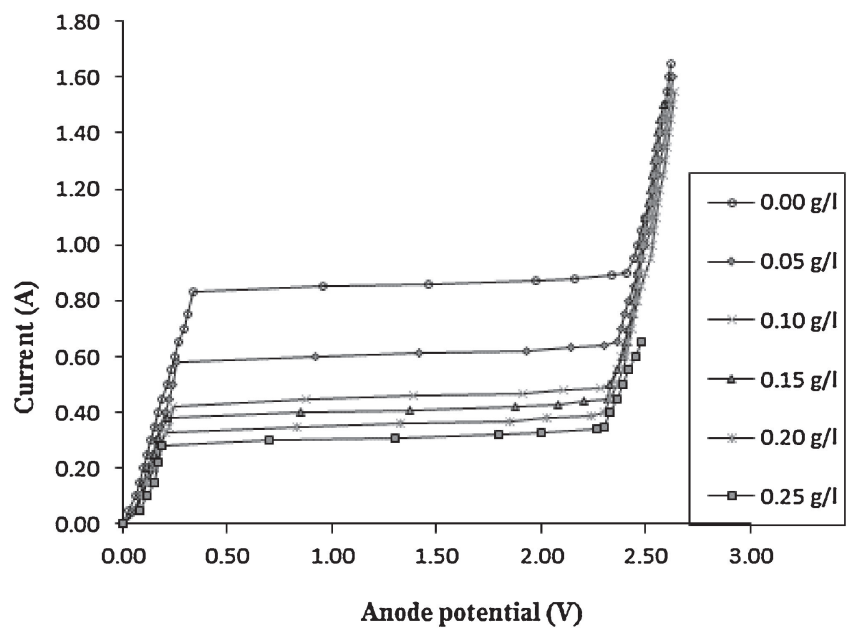

Figure 5. Typical polarization curves for steel in $8 \mathrm{M} \mathrm{H}_{3} \mathrm{PO}_{4}$ in presence of different concentrations of Hibiscus Sabdariffa at $298 \mathrm{~K}$.

Table 1. Values of limiting current $I_{L}(A)$, inhibition efficiency percentage (IE\%) for dissolution of steel in $\mathrm{H}_{3} \mathrm{PO}_{4}$ in the absence and presence of Hibiscus Sabdariffa at different temperatures and activation energy $E_{a}(\mathrm{~kJ} / \mathrm{mol})$.

\begin{tabular}{|c|c|c|c|c|c|c|c|c|c|}
\hline \multirow{2}{*}{$\begin{array}{c}\text { Conc. } \\
(\mathrm{g} / \mathrm{l})\end{array}$} & \multicolumn{2}{|c|}{$25^{\circ} \mathrm{C}$} & \multicolumn{2}{|c|}{$30^{\circ} \mathrm{C}$} & \multicolumn{2}{|c|}{$35^{\circ} \mathrm{C}$} & \multicolumn{2}{|c|}{$40^{\circ} \mathrm{C}$} & \multirow{2}{*}{$\begin{array}{c}\mathrm{E}_{\mathrm{a}} \\
\mathrm{kJ} / \mathrm{mol}\end{array}$} \\
\hline & $\mathrm{I}_{\mathrm{L}}$ & IE\% & $\mathrm{I}_{\mathrm{L}}$ & IE\% & $\mathrm{I}_{\mathrm{L}}$ & IE\% & $\mathrm{I}_{\mathrm{L}}$ & IE\% & \\
\hline 0.00 & 0.85 & 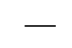 & 1.05 & 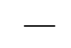 & 1.25 & 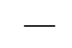 & 1.45 & - & \\
\hline 0.05 & 0.59 & 30.6 & 0.75 & 28.6 & 0.96 & 23.2 & 1.12 & 22.8 & 33 \\
\hline 0.10 & 0.46 & 45.9 & 0.58 & 44.8 & 0.77 & 38.4 & 0.94 & 35.2 & 37.66 \\
\hline 0.15 & 0.39 & 54.1 & 0.47 & 55.2 & 0.65 & 48.0 & 0.81 & 44.1 & 39.01 \\
\hline 0.20 & 0.34 & 60.0 & 0.43 & 59.0 & 0.58 & 53.6 & 0.72 & 50.3 & 39.56 \\
\hline 0.25 & 0.29 & 65.9 & 0.39 & 62.9 & 0.51 & 59.2 & 0.63 & 56.6 & 40.29 \\
\hline
\end{tabular}

the same range of concentrations using other anode geometry. ${ }^{22,23}$ The decrease in the limiting current with increasing $\mathrm{H}_{3} \mathrm{PO}_{4}$ acid concentration is attributed to three effects, a) the saturation solubility of $\mathrm{Fe}^{2+}$ phosphate in $\mathrm{H}_{3} \mathrm{PO}_{4}$ acid decreases with increasing $\mathrm{H}_{3} \mathrm{PO}_{4}$ acid concentrations with increasing $\mathrm{H}_{3} \mathrm{PO}_{4}$ concentration, which makes the onset of limiting current decreases. b) The viscosity of the solution increases with increasing $\mathrm{H}_{3} \mathrm{PO}_{4}$ acid concentration with consequent decrease in the diffusivity of $\mathrm{Fe}^{2+}$ ions according to the Stock-Einstein equation,

$$
\mathrm{D} \eta / \mathrm{T}=\text { constant }
$$

Where $\mathrm{D}$ is the diffusivity of $\mathrm{Fe}^{2+}$ ions $\left(\mathrm{cm}^{2} \mathrm{~s}^{-1}\right), \eta$ is the viscosity of solution $\left(\mathrm{g} \mathrm{cm}^{-1} \mathrm{~s}^{-1}\right)$ and $\mathrm{T}$ is the absolute temperature.

c) The increase in solution viscosity with increasing $\mathrm{H}_{3} \mathrm{PO}_{4}$ acid concentration results in an increase in the diffusion layer thickness which represent the resistance to the rate of mass transfer of $\mathrm{Fe}^{2+}$ ions from anode surface to the bulk solution.

\subsection{Corrosion of steel in $\mathrm{H}_{3} \mathrm{PO}_{4}$ with Hibiscus Sabdariffa}

Figure 5 shows Potentiodynamic polarization curves for steel in $8 \mathrm{M} \mathrm{H}_{3} \mathrm{PO}_{4}$ solution without and with various concentrations of extract of Hibiscus Sabdariffa at $298 \mathrm{~K}$. The values of $\mathrm{I}_{\mathrm{L}}$ are given in Table 1. The lower corrosion current values in the presence of the extract of Hibiscus Sabdariffa suggest that the compound act as inhibitor probably through adsorption on the surface thereby blocking the corrosion reaction. Inspection of Table 1 reveals that the $\mathrm{I}_{\mathrm{L}}$ decreases in the presence of Hibiscus inhibitor, and decreases with increasing the inhibitor concentration.

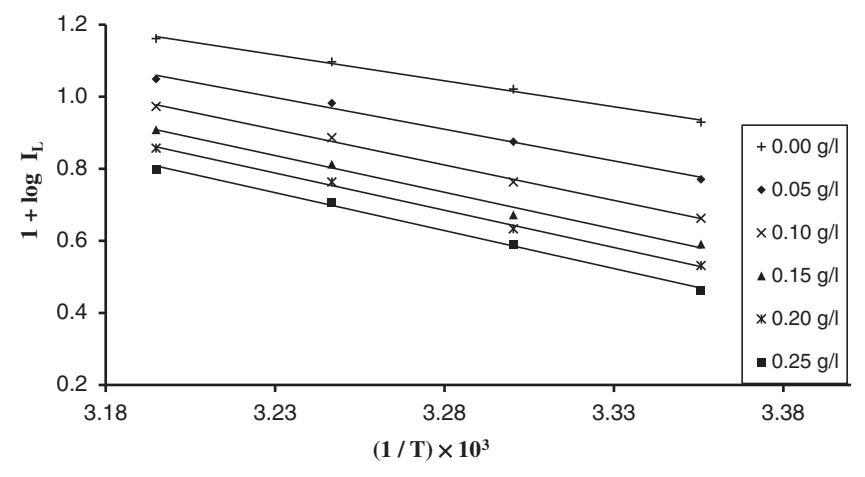

Figure 6. The Arrhenius plot of the dissolution process recorded for steel in $8 \mathrm{M} \mathrm{H}_{3} \mathrm{PO}_{4}$ solution containing different concentrations of Hibiscus Sabdariffa.

\subsection{Effect of temperature}

The effect of temperature on inhibition efficiency in $8 \mathrm{M} \mathrm{H}_{3} \mathrm{PO}_{4}$ containing various concentrations of inhibitor at temperature ranging from $298 \mathrm{~K}$ to $313 \mathrm{~K}$ is summarized in the Table 1 . It shows that the percentage of inhibition efficiency (IE\%) increases with the inhibitor concentration and decreases with increasing temperature. This could be explained on the basis that increasing temperature enhances the transfer rate of the $\mathrm{PO}_{4}^{-3}$ ions and increases the conductivity. So the dissolution rate may be affected by the transfer of the aggressive ions in the solution. Also the increase in temperature reduces solution viscosity with a consequent increase in $\mathrm{Fe}^{2+}$ diffusivity which leads to increase in the dissolution rate. ${ }^{24}$ Also decrease the IE\% is due to desorption of extract molecules from the steel surface by increasing temperature. The IE\% can be calculated from the $\mathrm{I}_{\mathrm{L}}$ values obtained from the polarization curves by using the formula,

$$
\mathrm{IE} \%=\frac{\mathrm{I}_{\mathrm{L}}(\text { blank })-\mathrm{I}_{\mathrm{L}}(\text { extract })}{\mathrm{I}_{\mathrm{L}}(\text { blank })} \times 100
$$

Where $\mathrm{I}_{\mathrm{L}(\text { blank) }}$ and $\mathrm{I}_{\mathrm{L} \text { (extract) }}$ are the limiting current values without and with inhibitor respectively.

The activation energies $\left(E_{a}\right)$ for the corrosion process in the absence and presence of inhibitor are evaluated from the Arrhenius equation: ${ }^{25}$

$$
\mathrm{I}_{\mathrm{L}}=\mathrm{A} \mathrm{e}^{(-\mathrm{Ea} / \mathrm{RT})}
$$

Where $\mathrm{A}$ is the pre-exponential factor, $\mathrm{R}$ the gas constant, and $\mathrm{T}$ is absolute temperature.

A plot of $\log \mathrm{I}_{\mathrm{L}}$ vs. $1 / \mathrm{T}$ gave a straight line as shown in Fig. 6 with a slope of $-E_{a} / 2.303 R$. The values of activation energy are listed in Table 1. The data show that the $\left(\mathrm{E}_{\mathrm{a}}\right)$ of the corrosion of steel in $8 \mathrm{M} \mathrm{H}_{3} \mathrm{PO}_{4}$ solution in the presence of the extract are higher than those in the free acid solution indicating that the corrosion reaction of steel is retarded by Hibiscus Sabdariffa and extract exhibit low IE\% at elevated temperature. The values of the activation energy reported in Table 1 which lie between 27.58 and $40.29 \mathrm{~kJ} / \mathrm{mol}$ are agreement with the value of diffusion controlled reaction. ${ }^{26,27}$

\subsection{Adsorption isotherm}

The surface coverage, $\theta$ values for different concentrations of the inhibitor were calculated using the following equation: ${ }^{28}$

$$
\theta=1-\frac{\mathrm{I}_{\mathrm{L}(\text { extract })}}{\mathrm{I}_{\mathrm{L}(\text { blank })}}
$$

Attempts were made to fit the $\theta$ values to various isotherms including Langmuir, Flory Huggins, and Kinetic-thermodynamic model. The data were tested graphically to find a suitable adsorption 
Table 2. Free energy of adsorption $-\Delta \mathrm{G}_{\mathrm{ads}}(\mathrm{kJ} / \mathrm{mol})$ at different temperatures and thermodynamic functions of adsorption process.

\begin{tabular}{cccccc}
\hline \multicolumn{4}{c}{$-\Delta \mathrm{G}_{\mathrm{ads}}(\mathrm{kJ} / \mathrm{mol})$} & $\Delta \mathrm{H}_{\mathrm{ads}}(\mathrm{kJ} / \mathrm{mol})$ & $\Delta \mathrm{S}_{\mathrm{ads}}(\mathrm{J} / \mathrm{mol} \mathrm{K})$ \\
\hline $25^{\circ} \mathrm{C}$ & $30^{\circ} \mathrm{C}$ & $35^{\circ} \mathrm{C}$ & $40^{\circ} \mathrm{C}$ & -29.39 & -47 \\
\hline 15.14 & 15.04 & 14.79 & 14.43 & & \\
\hline
\end{tabular}

isotherm. Plotting $\mathrm{C}_{\text {inh }} / \theta$ versus $\mathrm{C}_{\text {inh }}$ yielded a straight line with a higher correlation coefficient $\left(\mathrm{R}^{2}\right)$ and a slope closed to 1 (Fig. 7a) according to the following equation: ${ }^{29}$

$$
\mathrm{C}_{\mathrm{inh}} / \theta=1 / \mathrm{K}_{\mathrm{ads}}+\mathrm{C}_{\mathrm{inh}}
$$

Where $\mathrm{C}_{\mathrm{inh}}$ is the inhibitor concentration and $\mathrm{K}_{\mathrm{ads}}$ is the adsorption equilibrium constant to the inhibitor on steel surface.

This indicates that the adsorption can be fitted to a Langmuir adsorption isotherm. The equilibrium constant $\left(\mathrm{K}_{\mathrm{ads}}\right)$ can be calculated from the reciprocal of the intercept.

The equation of the Flory-Huggins isotherm is given by:

$$
\log \theta / \mathrm{C}=\log \mathrm{xK}+\mathrm{x} \log (1-\theta)
$$

Where $\mathrm{x}$ is the number of active sites occupied by one inhibitor molecule or number of water molecules replaced by one molecule of the adsorbate. The value of $\mathrm{x} \approx 1$ implied that one inhibitor molecule replaces one water molecule. The plot of $\log \theta / \mathrm{C}$ against $\log (1-\theta)$ is shown in Fig. 7b.

The kinetic-adsorption isotherm model is given by:

$$
\log (\theta / 1-\theta)=\log \mathrm{K}^{\prime}+\mathrm{y} \log \mathrm{C}
$$

Where $\mathrm{y}$ is the number of the inhibitor molecules occupying one active site. The binding constant $\mathrm{K}$ is given by:

$$
\mathrm{K}=\mathrm{K}^{\prime 1 / \mathrm{y}}
$$

The slope $\mathrm{y}$ of the linear relation between $\log (\theta / 1-\theta)$ versus $\log \mathrm{C}$ (Fig. 7c) is closed to unity, it means that the additive molecule occupied one active site.

\subsection{Thermodynamic data of adsorption}

The free energy of adsorption $\left(\Delta \mathrm{G}^{\mathrm{o}}\right.$ ads $)$ at different temperatures was calculated from the equation: ${ }^{30}$

$$
\Delta \mathrm{G}^{\mathrm{o}}{ }_{\mathrm{ads}}=\mathrm{RT} \ln 55.5 \mathrm{~K}_{\mathrm{ads}}
$$

Where, $\mathrm{R}$ is universal gas constant, $\mathrm{T}$ is temperature $(\mathrm{K})$ and $\mathrm{K}_{\mathrm{ads}}$ is equilibrium constant.

The negative values of $\Delta \mathrm{G}^{\mathrm{o}}$ ads suggest spontaneous adsorption of the inhibitor and usually characterize their strong interaction with the metal surface. The increase in the values of $\Delta G_{\text {ads }}^{o}$ with increasing temperature indicates that the adsorption was unfavorable with increasing the reaction temperature as the result of the inhibitor desorption from the steel surface. ${ }^{31}$ For a physical adsorption mechanism, the value of the free energy of adsorption $\left(\Delta \mathrm{G}^{\mathrm{o}}{ }_{\mathrm{ads}}\right)$ should be more negative than $-40 \mathrm{~kJ} / \mathrm{mol}$; therefore the data are consistent with physical adsorption mechanism. ${ }^{32,33}$

The change in enthalpy $\left(\Delta \mathrm{H}_{\mathrm{ads}}\right)$ and the change in entropy $\left(\Delta S_{\text {ads }}\right)$ are calculated from the values of free energy of adsorption $\left(\Delta \mathrm{G}_{\mathrm{ads}}\right)$ by Gibbs Helmholtz relationship,

$$
\Delta \mathrm{G}_{\mathrm{ads}}=\Delta \mathrm{H}_{\mathrm{ads}}-\mathrm{T} \Delta \mathrm{S}_{\mathrm{ads}}
$$

By plotting $\Delta \mathrm{G}_{\text {ads }}$ vs. T gives the slope $\Delta \mathrm{S}_{\mathrm{ads}}$ and intercept $\Delta \mathrm{H}_{\mathrm{ads}}$. The values of entropy and enthalpy of adsorption are $-47 \mathrm{~J} / \mathrm{mol} \mathrm{K}$ and $-29.39 \mathrm{~kJ} / \mathrm{mol}$ respectively.

The negative value of $\Delta \mathrm{H}_{\mathrm{ads}}$ indicates that the adsorption of inhibitor molecules on the metal surface is an exothermic reaction. The negative value of $\Delta \mathrm{S}_{\mathrm{ads}}$ indicates a reduction of translation
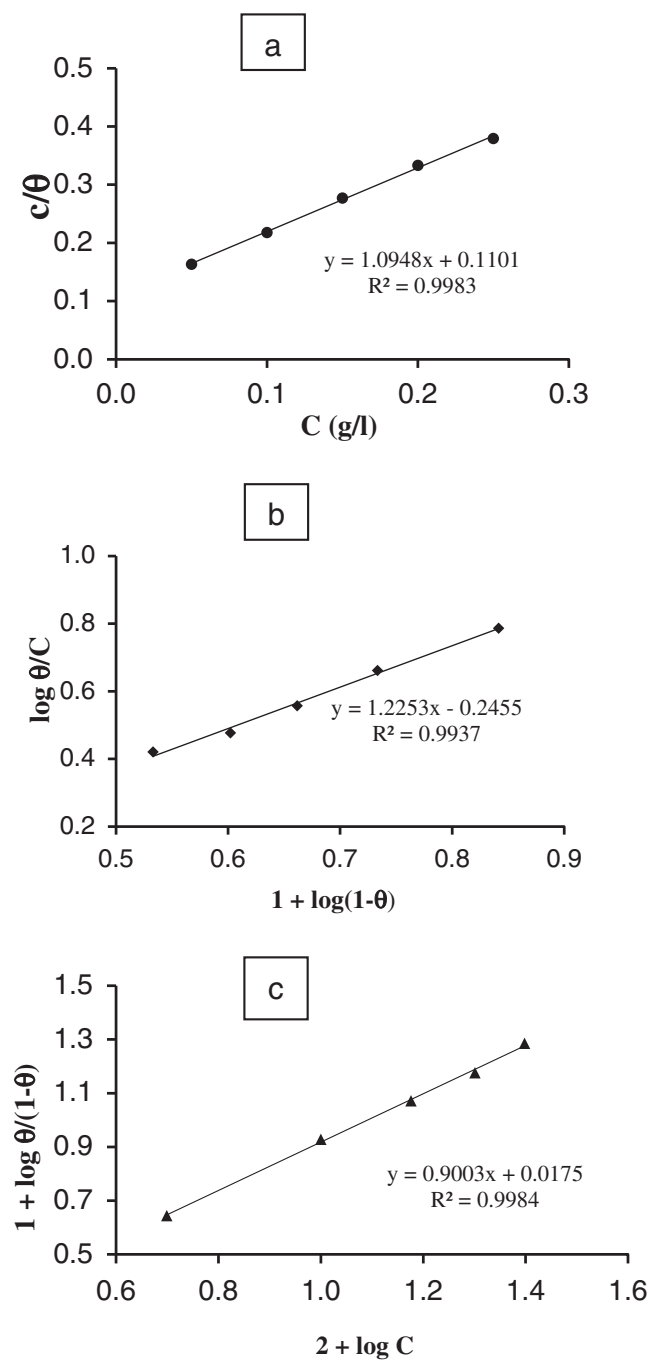

Figure 7. Adsorption isotherm plots for the adsorption of Hibiscus Sabdariffa in $8 \mathrm{M} \mathrm{H}_{3} \mathrm{PO}_{4}$ on the surface of steel at $298 \mathrm{~K}$ a) Langmuir isotherm b) Flory-Higgins isotherm c) Kinetic isotherm.

degree of freedom and show a decrease in the system disorder. The negative values of $\Delta \mathrm{G}^{\mathrm{o}}$ ads suggest a strong interaction of the inhibitor molecules and spontaneous adsorption of inhibitor on steel surface. The obtained are indicative of physisorption (Table 2). ${ }^{34}$

\subsection{SEM measurements}

SEM of the polished surface of the steel exposed in $8 \mathrm{M} \mathrm{H}_{3} \mathrm{PO}_{4}$ solution in the absence and presence of Hibiscus extract were shown in Fig. 8. To confirm the formation of the films on the steel surface, SEM technique was used to characterize the steel surface. Figure $8 \mathrm{a}$ shows the surface image of steel sheet after polishing. Its surface is a rough surface on steel in the absence of the extract. There was a smooth surface with deposits extract on it in the presence of the extract (Fig. 8b). ${ }^{35}$ This result confirms that the extract inhibited corrosion of steel through adsorption of the inhibitor on the metal surface.

\section{Conclusion}

Acid extract of Hibiscus acts as a good corrosion inhibitor for steel in $8 \mathrm{M} \mathrm{H}_{3} \mathrm{PO}_{4}$. Inhibition efficiency increases with inhibitor concentration and maximum inhibition efficiency was $65.9 \%$ of the inhibitor concentration and decreases with a rise in temperature. Potentiodynamic polarization measurement shows that it acts as 


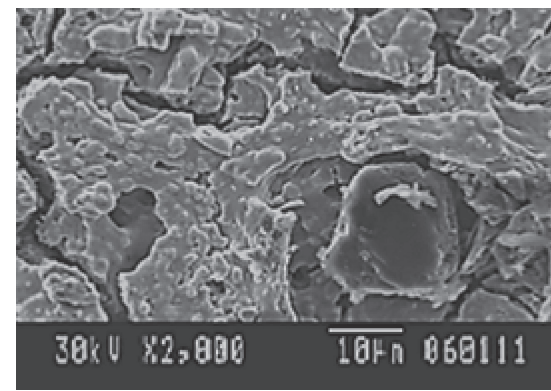

(a)

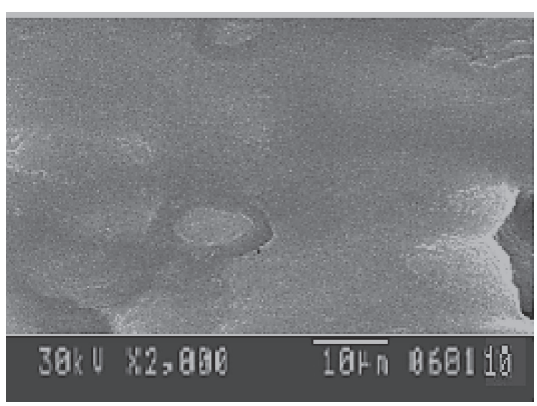

(b)

Figure 8. Surface morphologies of the steel at $298 \mathrm{~K}$ after electrodissolution in a) $8 \mathrm{M} \mathrm{H}_{3} \mathrm{PO}_{4}$ b) in the presence of $0.25 \mathrm{~g} / 1$ Hibiscus extract.

anodic inhibitor. The increase in the values of the activation energy of corrosion process in the presence of the extract indicates that Hibiscus extract retards the rate of corrosion. Adsorption models isotherm fit well as evidence from the correlation coefficient values. This proves the applicability of all the models in the process. The SEM study confirms that the inhibition of corrosion of steel is through adsorption of the extract on the surface of metal.

\section{References}

1. L. X. Que and L. V. Thu, J. Chem., 48, 574 (2010).

2. P. B. Raja and M. G. Sethuraman, Mater. Lett., 62, 113 (2008).
3. O. K. Abiola and A. O. James, Corros. Sci., 52, 661 (2010).

4. M. A. Abdel Rahim, H. B. Haasan, and M. W. Khalil, Materialwiss. Werkstofftech., 28, 98 (1997).

5. F. Bentiss, M. Bouanis, B. Mernari, M. Traisnel, H. Vezin, and M. Lagrenee, Appl. Surf. Sci., 253, 3696 (2007).

6. E. A. Noor, Corros. Sci., 47, 33 (2005).

7. Y. Tang, X. Yang, W. Yang, R. Wan, Y. Chen, and X. Yin, Corros. Sci., 52, 1801 (2010).

8. R. Saratha, C. Marikannu, and S. Sivakamasundari, Bull. Electrochem., 18, 141 (2002).

9. H. Ashassi-Sorkhabi, B. Shaabaniss, and D. Seifzadeh, Electrochim. Acta, 50, 3446 (2005).

10. M. Behpour, S. M. Ghoreishi, N. Soltani, and M. Salavati-Niasari, Corros. Sci, 51, 1073 (2009).

11. A. Y. El-Etre, Appl. Surf. Sci., 252, 8521 (2006).

12. A. K. G. Satapathy, G. Sahoo, S. C. Amit, and P. V. Kumar Rodrigues, Corros. Sci., 51, 2848 (2009).

13. C. Jeyaprabha, S. Sathiyanarayanan, and G. Venkatachari, J. Electroanal. Chem., $\mathbf{5 8 3}, 232(2005)$

14. M. M. Osman, R. A. El-Ghazawy, and A. M. Al-Sabagh, Mater. Chem. Phys., 80, 55 (2003).

15. A. Y. El-Etre, J. Colloid Interface Sci., 314, 578 (2007).

16. M. Quraishi and H. Sharma, J. Appl. Electrochem., 35, 33 (2005).

17. S. A. Ali, M. T. Saeed, and S. U. Rahman, Corros. Sci., 45, 253 (2003).

18. M. Bouklah, A. Ouassini, B. Hammouti, and A. El Idrissi, Appl. Surf. Sci., 252, 2178 (2006)

19. C. C. Chen, J. D. Hsu, and S. F. Wang, J. Agric. Food Chem., 51, 5472 (2003).

20. Q. Y. Deng, L. Liu, and H. M. Deng, Principles of Spectrometric Identification, $2^{\text {nd }}$ Edition, Science Press, Beijing, 37 (2007).

21. L. B. Molina-Ocampo, M. G. Valladares-Cisneros, and J. G. Gonzalez-Rodriguez, Int. J. Electrochem. Sci., 10, 388 (2015).

22. M. M. Zaki, I. Nirdosh, and G. H. Sedahmed, Int. Commun. Heat Mass Transfer, 27, 435 (2000).

23. I. Nirdosh and G. H. Sedahmed, Int. Commun. Heat Mass Transfer, 23, 633 (1996).

24. M. A. Amin, M. A. Ahmed, H. A. Arida, T. Arslan, M. Saracoglu, and F. Kandemirli, Corros. Sci., 53, 540 (2011).

25. A. M. Fekry and Riham R. Mohamed, Electrochim. Acta, 55, 1933 (2010).

26. A. Popova, M. Christov, and A. Vasilev, Corros. Sci., 49, 3276 (2007).

27. M. M. Solomon, S. A. Umoren, I. I. Udosoro, and A. P. Udoh, Corros. Sci., 52, 1317 (2010).

28. L. G. Trindade and R. S. Gonçalves, Corros. Sci., 51, 1578 (2009).

29. S. A. Abd El-Maksoud and A. S. Fouda, Mater. Chem. Phys., 93, 84 (2005).

30. I. Ahamad, R. Prasad, and M. A. Quraishi, Corros. Sci., 52, 1472 (2010).

31. L. Tang, G. Mu, and G. Liu, Corros. Sci., 45, 2251 (2003).

32. A. Popova, E. Sokolova, S. Raicheva, and M. Christov, Corros. Sci., 45, 33 (2003).

33. A. A. Taha, H. H. Abdel Rahman, and F. M. Abouzeid, Int. J. Electrochem. Sci, 8, 6744 (2013).

34. A. Y. El-Etre, Corros. Sci., 45, 2485 (2003).

35. X. Sheng, Y. P. Ting, and S. O. Pehkonen, Ind. Eng. Chem. Res., 46, 7117 (2007). 